\title{
The Application of Social Control Theory in Preventing Violent Crime by Juvenile Delinquent
}

\author{
Yeni Widowaty \\ Master of Law Universitas Muihammadiyah Yogyakarta, Indonesia. E-mail: yeniwidowaty@umy.ac.id
}

\begin{tabular}{|c|}
\hline ARTICLE INFO \\
\hline $\begin{array}{l}\text { Keywords: } \\
\text { juvenile deliquent, } \\
\text { prevention, social control } \\
\text { theory, violent crime. }\end{array}$ \\
\hline $\begin{array}{l}\text { How to cite: } \\
\text { Widowaty, Y., (2019) The } \\
\text { Application of Social } \\
\text { Control Theory in } \\
\text { Preventing Violent Crime } \\
\text { by Juvenile Deliquent. } \\
\text { MEDIA HUKUM, }+62 \\
274387656 \text { (Ext. 220) }\end{array}$ \\
\hline $\begin{array}{l}\text { Article History: } \\
\text { Received: } 21-10-2-19 \\
\text { Reviewed: } 05-11-2019 \\
\text { Revised: } 21-12-2019 \\
\text { Accepted: } 23-12-2019\end{array}$ \\
\hline
\end{tabular}

\begin{abstract}
Yogyakarta has faced a number of violent crimes committed by a group of teenagers (juvenile delinquents). These include vandalism, destruction of public facilities and even murder. The purpose of the research was to find out factors that contribute to the rise of such crimes in Yogyakarta and the possible solutions. This Socio-Legal research employed both primary and secondary data. It was found that factors causing violent crimes derived from both internal and external factors of the perpetrators. Both penal and non-penal policies have been taken to prevent the mentioned crimes. The future concept is to approach violent crimes by juvenile delinquents through Social Control theory in the form of affection, trust, commitment, and involvement. The idea is to involve various parties in handling the problem. Not only police officers, other stakeholders such as parents, teachers, and religious leaders should also be involved.
\end{abstract}

DOI: 10.18196/jmh.20190133

Copyright @ 2019 MEDIA HUKUM. All rights reserved.

\section{Introduction}

Efforts to meet and create a sense of security in the community is a strategic step that also influences the success of national development. The creation and fulfillment of a sense of security in the community will build a conducive atmosphere for the community to conduct various activities, including economic activities. This condition, in a macro scale, will create national stability, which is one of the prerequisites for the achievement of development in order to realize a just and prosperous society.

Yogyakarta has faced a number of violent crimes committed by a group of teenagers (juvenile delinquents).According to data from Yogyakarta Provincial Police, at least 43 cases of violent crime occurred in Yogyakarta in 2016. This number was spread in five districts; Sleman (21 cases), Bantul (15 cases), Gunung Kidul (4 cases), Kota Jogja (2 cases) and Kulonprogo (1 case). ${ }^{1}$ The rise of violent crime on the streets has recently

1 Arifi, K. A . (2017). Jogja Masih Darurat Klitih. Pranala. Edition 14. Maret-April 2017. 
invited public unrest. Not only provoke terror, these street crimes often injure or take the lives of innocent victims. As educational and cultural city, Yogyakarta has long been known for its calm, polite, and peaceful atmosphere. Therefore, the emergence of violent crimes is surprising and best solution is needed. In order to solve the problem, it is necessary to trace it back to its root. In this regards, the social control theory will be used to approach the mentioned problems.

The problem of the research has been formulated as follows:

a.How to prevent violent crimes by juvenile delinquencts in Yogyakarta?

b.Can the social control theory be employed as approach in combating future violent crimes by juvenile delinquents?

Based on the above-mentined problems, then the purposes of the research are as follows:

a. Reviewing and analyzing the prevention of violent crimes by juvenile delinquents in Yogyakarta.

b. Formulating the ideal model of combating violent crimes by juvenile delinquents based on the social control theory approach.

\section{Methods}

The type of the research is socio-legal or empirical legal research aiming at discovering theories relating to the impact of law in society ${ }^{2}$ and investigating the its relation with other social phenomena. ${ }^{3}$ Both primary and secondary data were used. Primary data was obtained through interviews with relevant parties, especially the perpetrators and the family of the victims. Secondary data that consists of primary, secondary and tertiary legal material were collected through library-based study. Primary data are in the forms of statutory and legal documents, while secondary legal material are in the forms of books and legal writings. What's so called tertiary legal material is a legal material that provides explanation for primary and secondary legal material. ${ }^{4}$

The research was conducted in Yogyakarta and employed samples from Sleman, Kota Yogyakarta and Bantul where violent crime cases frequently occured. The data obtained were analyzed using flow models of analysis. ${ }^{5}$ Analytical and critical analysis has been exercised to present qualitative data.

\footnotetext{
2Zainuddin Ali. (2013). MetodePenelitianHukum. Jakarta: SinarGrafika. p.13.

${ }^{3}$ Atmasasmita, R . (2009). Perbandingan Hukum Pidana Kontemporer. Jakarta: Fikahati Aneska. p. 27.

${ }^{4}$ Ibrahim, J. (2007). Teori E Metodologi Penelitian Hukum Normatif. Malang: Bayumedia Publishing. p. 296.

${ }^{5}$ Miles, M B \& Huberman, A. M. (1992). Analisis Data Kualitatif. Jakarta: UI Press. p.19-20.
} 


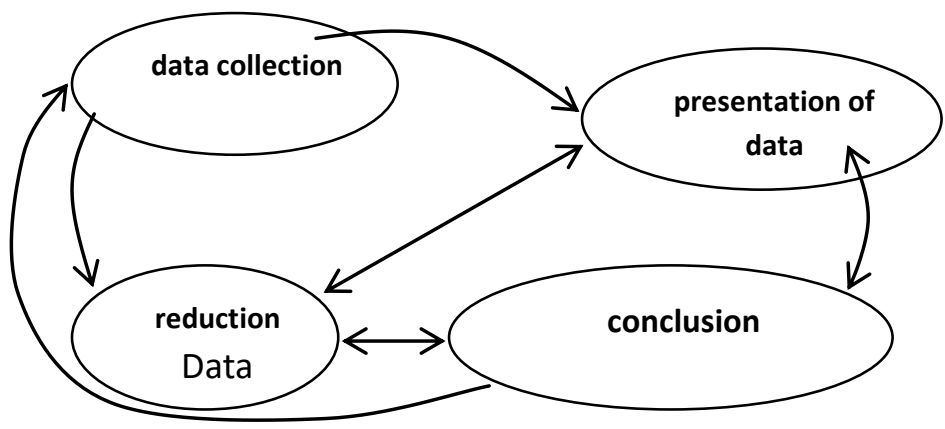

\section{Analysis and Results}

\subsection{Factors that Cause Violent Crimes by Juvenile Delinquent in Yogyakarta}

Violent crimes on the streets by juvenile delinquent are unimaginable for the victims. There have been several cases of violent crime involving teenagers in Yogyakarta. There was a person encountering people who demand money while driving on a barren road. These people pointed a weapon against the victim while asking for money. There was also a person being immediately attacked by drunken teens when driving. The targets of these juvenile delinquents are not specific and can happen to anyone, such as students, women, and other members of the society. These are the today's reality in Yogyakarta, a region which have long time known for its politeness and friendliness.

In Yogyakarta, violent crimes committed by juvenile delinquent has commonly been referred to as 'klitih' and this constitutes a new phenomenon. There is no standard definition of klitih. Literally, klitih refers to the activity of leaving the house at night to hunt for food. Now, this term has been shifted to the activity of a school gang moving arround, usually after school, by riding motorcycles in lonely streets for looking for their rivals from other schools. Although their primary targets are students, however anyone who passes through are also vulnerable from victimization.

From legal perspective, since klitih is a more sociological term, this term can be found in any legislation. However, there are some staturory provisions relevant to this issue. The Indonesian Penal Code governs several forms of violent crimes including rape (Article 285), Persecution (Article 351), and extortion (Article 368).

Martin L. Haskel and Lewis Yablonsky suggest four categories violence as follows:

a. Legal Violence

This violence may take the form of aggression, which is supported by the law. For example, soldiers perform tasks in war, as well as violence that justified legally, such as boxing sport as well as actions to defend themselves.

b. Violence Socially Have Sanctions

An essential factor in analyzing violence is an act of support or sanctions against it, such as the act of a husband over the fornicators will gain social support.

c. Rational Violence

Some of the illegal acts of violence but no social sanction are a crime that is considered reasonable in the context of an offense. For example, homicide the framework of organized crime. 


\section{d. Unlawful Violence}

Crimes that are the result of provocation, without the perpetrator showing a known motivation to act against the victim. It can be classified as 'raw' violence, a direct expression of a person's psychic disorder within a particular moment in his life.

Various causes of violent crime can be traced to both internal and external factors. Internal factors can take the form of emotional immaturity that manifests into temperamental behavior. Personality diseases can also encourage criminal behavior on the street. While external factors can be due to exposure to violence on television or the internet. These, directly or indirectly, give examples to the teenagers to commit a crime on the streets. The vulgar coverage of violence by motorcycle gang in various areas, students' brawl views on the streets, live looting and burning reports, could be a trigger for someone to commit the same actions. Another external factor is the social environment. Those who associate with negative people are susceptible to and follow their negative behaviors. ${ }^{6}$

In this regard, Soeprapto explains that one of them has strong influence among the group members and is able to drive them to commit violence. This figure can be an active student in one school or one who has graduated from the school. They want that their existence to be recognized by anyone. ${ }^{7}$

Teenagers committed violence in various ways, including using sharp weapons. The following table shows the variety of violences involving teenagers in Sleman and Bantul Districs.

Table 1. Violence by Teenagers at DIY in 2016-April 2017

\begin{tabular}{|c|c|c|c|c|c|c|c|}
\hline \multirow{3}{*}{ Cases } & \multicolumn{2}{|c|}{ Yogyakarta } & \multicolumn{2}{|c|}{ Bantul } & \multicolumn{3}{|c|}{ Sleman } \\
\hline & Year & & Year & & Year & & Amount \\
\hline & 2016 & 2017-April & 2016 & 2017-April & 2016 & 2017-april & \\
\hline $\begin{array}{l}\text { The Use of } \\
\text { Sharp }\end{array}$ & 10 & 2 & 11 & 2 & 12 & 4 & 41 \\
\hline $\begin{array}{l}\text { Weapon } \\
\text { Grave } \\
\text { Criminal }\end{array}$ & 10 & 3 & 6 & 1 & 7 & 2 & 29 \\
\hline $\begin{array}{l}\text { Drinking } \\
\text { Liquor }\end{array}$ & 1 & - & 10 & 2 & - & - & 13 \\
\hline Vandalism & 1 & - & 1 & - & - & - & 2 \\
\hline Persecution & 10 & 2 & 8 & 5 & 4 & 1 & 30 \\
\hline Total & 32 & 7 & 36 & 10 & 23 & 7 & 115 \\
\hline
\end{tabular}

Source: Yusuf Arko Priambodo

According to the above table, the use of weapon are dominant. It seems to be necessary to refer to Dodit's story, one of the klitih victim, to understand the situation. One day when Dodit was riding his motorcycle, eight people with four motorcycles came and suddenly grazed and kicked him until fell down on the road. They just left away after

6krjogja.com. 2016. Menekan 'CahKlitih' di Yogyakarta. Accessed on Tuesday 23 January 2018 08.30.

7Kriminalitas.com. 2016. Ini Penyebab Aksi Klitih Terjadi di Yogyakarta. Accessed on Tuesday 22 Januari 201810.49 
giving some extra kicks to him. ${ }^{8}$ Such attack was less serious, in some other cases even the attacks have caused serious injury or even death

Violence may occur in the school environment as well as outside the school. According to Ahmad Dofiri, the former Chief DIY Police, based on the police investigation cases of violence by juvenile delinquents in Yogyakarta (klithih) involve the role of school gangs. ${ }^{9}$ The existence of these gangs have been identified and mapped by the DIY police. As a summary, there are 81 school gangs altogether which are spread out in Yogyakarta City (35 gangs), Sleman District (27 gangs), Bantul District (15 gangs) and Kulon Progo District (1 gang) and Gunung Kidul (1 gangs). ${ }^{10}$

According to Sepuh A.I Siregar, ${ }^{11}$ there are two motives of joining the gangs which later lead the teenagers to involve in crime of violence. First, those who just follow the gang. Second, problematic children. These kids do not attend school; his association is not clear; his job is unclear, which then they clustered to persecute. Of these two groups, the way they play is different. For the typical gang, they drink then they extort victims in the vicinity. While the school gangs usually look for the members of other school gangs (school enemies). They usually do their actions on Magelang street, Denggung area, until Cebongan. The victims are often young people.

\subsection{Prevention of Violent Crime by Juvenile Delinquent in Yogyakarta}

Preventing the violent crimes by juvenile delinquents involves both penal anad nonpenal policies. With regard to the non-penal policy, crime prevention can employs social control theory. According to G.P. Hoefnagels as quoted by Barda Nawawi Arief, 12 the countermeasure of crimes can be done through:

a. Application of criminal law;

b. Prevention without punishment;

c. Influencing people's views on crime through mass media.

According to Sarlito Wirawan Sarwono, ${ }^{13}$ to reduce the conflicts of teenagers, people need to create the nearest environmental conditions as stable as possible, especially the family environment. A harmonious family (characterized by a harmonious marital relationship of parents) will be a better place for the teens to grow up and undergo their transitional process as compared to the broken family.

When children must leave their homes due to family problems (divorce or death), they should move to another harmonius family to secure their personality development. In case they will stay in dormitories or other child care institutions such as orphanage,

\footnotetext{
8 Arifin, K. A. (2017). Jogja Masih Darurat Klitih. Pranala Edition 14.

9 The statement was delivered in a seminar on "Strategy to Realize Jogja Free Klitih" held in Yogyakarta on March 16, 2017.

${ }_{10}$ Menelisik Asal Mula Klitih di Yogyakarta. (2017), https://www.kompas.com/tren/read/2020/01/14/060000165/menyelisik-awal-mula-munculnya-klitihdi-yogyakarta?page=all . Accessed January 23, 2018.

11 (Kasat Reskrim Polres Sleman).

12 Muladi \& Arief, B.N. (2005). Teori-Teori dan Kebijakan Pidana. Bandung. p.152

13 Dwi, G. M. (2013). Criminal Violence Action by The Students And Their Responsibility Efforts (Case Study In The Area Of Police Klaten). Faculty of law. University Muhammadiyah of Surakarta.
} 
these mentioned alternative places should also adopt the harmonius family circumstances."

People in Yogyakarta feel no longer safe on the street, especially at certain hours at night. Some people think the city of Yogyakarta has already been in the emergency of "klitih." Several cases of violence on the streets have changed the face of Yogyakarta as a peaceful city. These include victimization against Ilham Bayu Fajar, 17 years old, a junior high school student ${ }^{14}$ by a group of teenagers in Jalan Kenari Yogyakarta early morning on Sunday, March 12, 2017 and died accordingly. Klitih also has also took another life in December 2016. The victim was Adnan Wirawan Ardiyanta (16 years old), student of Muhammadiyah 1 Yogyakarta Senior high school. ${ }^{15}$

In order to be able to address problems relating to klithih in Yogyakarta, special approach seems to be necessary. Teenagers should be guided to positive behavior. In their age, when seeking personal identity is an ultimate affair, teenagers love challenges and freedom. These psychological condition should be considered especially by families and schools. For example, students who have big dough and have excessive power, they can be suggested to join martial arts, so they can express their hobbies into positive activities. They can also be encouraged to join advanture activities. Those who are famous and provocative can be adviced to join student organizations at school so they can use their influences to lead other students into positive activities.

Various efforts are needed to overcome violent problems involving teenagers (klithih). Police raids and patrols against violent crimes remain necessary. Law enforcement against the trade of liquor and its consumption must be intensified. In addition, the parents should pay serious attention to their family members. Family is the main factor and essential in shaping children's behaviors. Compassion from this smallest environment will pevent the children from going out.

Barda Nawawi Arief, 16 explains that any action to prevent and combat crimes is under the area of criminal policy. Criminal policy is derived from the broader policy namely Social Policy. The concept of Social Policy covers strategies for achieving social welfare and procedures for protecting the society. Crime prevention carried out by means of criminal law (penalty), should pay attention to and lead to the achievement of the objectives of the social policy in the form of "social welfare" and "social defense."

According to Arief as quoted by Winowoda, criminal policy can be divided into two namely penal policy and non-penal policy. ${ }^{17}$ Accordingly, efforts to overcome criminality can also employ both penal efforts and non-penal efforts.

\footnotetext{
14 SMP Piri 1 Yogyakarta.

15 Tempo.co. 2017. DPRD Yogyakarta Rencanakan Raperda Atasi Aksi Klitih( DPRD Yogyakarta PlanBill of Local regulation Overcome Action Klitih). Accesssedm on Tuesday 14 March 2017 22:06

16 Arief, B. N. (2008). Bunga Rampai Kebijakan Hukum Pidana (Perkembangan Penyusunan Konsep KUHP Baru (Cultivation Interest of Criminal Law Policy (Development of Drafting of New Criminal Code). Jakarta: Kencana Pernada. p. 49.

17 Winowoda, D. (2015). “Kebijakan Penanggulangan Kejahatan Kekerasan Dalam Rumah Tangga Di Kota Manado". Lex Crimen. IV(4):
} 


\section{a. Penal Efforts}

It emphasizes repressive measures that will be made after the crime occurred. Repressive efforts is intended to crack down on the perpetrators of crimes in accordance with their actions and fix them back so that they realize that his actions violate the law and harm the community. Hence, they do not repeat it, and others can learn not to do it considering the heavy sanctions.

\section{b.Non-Penal Efforts}

It focuses on precautionary measure whose target is to address the stimulating factors criminal behaviours. These include social problems or social conditions that directly or indirectly can cause criminality. Non-penal efforts is crucial and strategic in crime prevention.

The research finding shows Yogyakarta police have used both preventive and repressive measures in dealing with violent crimes by juvenile delinquents. Prevention has been done by patrolling around both in school hours and at night. Besides, Yogyakarta Police also summoned all principals of both senior high school and junior high school and the Education Officers several times. The goal is to encourage the schools for supervising their students in attempt to avoid anarchism. These preventive measures have been taken by the residents of Manggung Caturtunggal Depok Sleman and also the police in Sleman. These action has successfully captured 11 people who behaved suspiciously. After being searched, they brought iron, wooden batons, and even stone. This happened at 2:30 in the morning at the northern ringroad. ${ }^{18}$ The age of the perpetrators ranged from 15 years to 20 years, all of whom were high school students, and only one was unemployed. The motive of the perpetrator is just hanging around, no specific purpose. They feel satisfied if someone got hurt. They also did not take the victim's belongings while repressively acted as violent criminals, especially klitih. If the perpetrator is still under 18 years old then use law number 12 of 2012 on Children Court Act.

\subsection{The Use of Social Control Theory to Overcome Violent Crimes by Juvenile Delinquents: Future Approach}

Crime prevention strategy can be effective only if it adresses the causes of crime. In fact, some causes of crime cannot be identified by the police. Preventing crime requires improvement of certain conditions. The police must transfer criminological terms to the public. ${ }^{19}$

John Hagan asserted that social control theory departs from the assumption that every individual in society has the same opportunity to become a person breaking the law or people who obey the law. The social control theory asks the fundamental question, why doesn't everyone break the law or why it exists people who follow the law. ${ }^{20}$

\footnotetext{
18 Roda2blog.com. (2016). Tampang 11 Remaja Geng Klitih Yang Meresahkan Warga Jogjakarta (Appearance 11 Teens Gang Klitih Who Disturbs the citizens of Yogyakarta).Accessed on 23 January 2018 12.34

19 Djanggih, H \& Qamar, N. (2018). Penerapan Teori-Teori Kriminologi dalam Penanggulangan Kejahatan Siber (Cyber Crime). Research Law Journal. 13(1): 10-23.

${ }^{20} \mathrm{Ibid}$.
} 
The delinquent behavior depends on many factors including parenting, family and social inheritance, lifestyle of friendships, social environmental demands, anxieties, and social norms that deprive the youth of their own identity. Therefore, violence by the youth in Yogyakarta is a complex phenomenon. The solution can not solely be assigned to the police. All stakehlders must be involved especially schools and families.

The engagement refers to the bonds on the other side (such as family and peers) as well as essential institutions, eg schools, churches, and mosques. Commitment deals with the extent to which a person maintains an interest in the social and economic system about how society nurtures or fosters social control and how to obtain conformity or failure to achieve it in the form of perversion. The perpetrators of violent crime are many who come from a broken home family or children who, at times, small often experience violence. These children then show their identity and move in search of the enemy.

The regional government has tried to minimize the occurrence of violence by teenagers, especially students, but the klitih phenomenon still exists. Therefore, there is a need to approach this phenomenon in different way. Approaching the phenomenon of klitih using the non-penal system seems to be more appropriate. In this regards, the use of social control theory is aadvocated.

Social control theory adopted in this study refers to one proposed by Travis Hirschi who comes up with the idea of "social bond." Social bond theory from Travis Hirschi suggest four approaches namely attachment, commitment, involvement and belief.

a. Attachment is the human ability to involve itself against others. If this attachment has been formed, then the person will be sensitive to the thoughts, feelings, and desires of others. Attachments are often interpreted freely with bonds. The first bond is the attachment to the parents, the attachment to the school (teacher), and attachment with peers.

b. Commitment is the attachment of a person on a conventional sub-system such as school, work, organization, and so on. Commitment is a rational aspect of social bonding. Any individual activities such as school, work, activities within the organization will benefit the person.

c. Involvement is the activity of a person in the conventional system sub. If someone involved in an organization is small, he will develop a tendency to commit irregularities. The logic of sense is when people participate in many activities so that they would spend time and energy in respect of such events. It decreases chances for them to commit acts against the law in the future.

4) Beliefs, the moral aspect is contained in social bonding and undoubtedly different from these three issues above. Belief is the faith of a person on moral values. Trusting someone against existing norms gives rise to adherence to the standard.

All components above should be formed in society according to Hirschi. If it fails, then teenagers would use rights to violate.

Sociological theories are looking for the reasons for the difference in terms of the number of crimes in the social environment. These theories can be divided into three 
groups namely: Strain; Cultural Deviance; and Social Control. ${ }^{21}$ Social control theory relies on assumption that motivation to do evil is part of the human race. As a consequence, this theory attempts to explain why people do not commit crimes.22 According to Travis Hirschi, there are four elements of social ties (social bond) in any society.

It is primarily for softening violent crimes that do not result in the death of the victim. Some routine activities before the crime can be done several alternatives:

a. The first is done by collecting the parents in each school, especially the children who have problems with the law so that issues related to the child can be submitted and resolved.

b. Another step to multiply extra lessons according to the talents of students, for example, some like fighting in fun boxing. (engagement)

c. The troubled alumni are prohibited from coming to school to avoid affecting their younger relatives.

d. It is recommended to go home immediately after school and to hang around.

In addition to these steps, the District will continue to monitor and cooperate with the Education Office and Schools, especially Senior High School and Junior High School. Actions are taken by Mayor Regulation (Perwal) No. 24 of 2008 and Perwal No. 41 of 2010 on Guidelines for the Preparation of School Order, which must be followed by Principal Regulations in each school.

The regulation provides that every student who involved in brawl will be returned to parents or expelled from the school. Many students in Yogyakarta are worried about the existence of the Mayor's Regulation. They are afraid of being expelled from school if they do brawl. As a result, the intensity of brawl between students decreased significantly. In other words, the Mayor Regulation deters students from fighting.

The mayoral regulation needs to be reformulated in order to cover other cases. As suchm not only students who are brawling are returned to their parents; those who involved in legal cases or wandering at school hours will also be subjected to that administrative sanction. In addition, if the acts have harm others, the perpetrators must be sanctioned in accordance with the existing law, especially criminal law. Perpetrators whose age does not exceed 18 years is subjected to the Children Court System Act 2012 (Law No. 11 of 2012 on Children Acourt System). This law offers restorative justice approach and diversion. These are so to avoid the children from judicial process in order to prevent stigmatization of children in conflict with the law. It is expected that the children can reasonably return to their social environment.

The aims of diversion according to section 6 of the Children Court System Act 2012 are:

a. To achieve peace between the victim and the child;

b. To resolve cases of children outside the judicial process;

c. To prevent the child from deprivation of liberty;

${ }^{21}$ Santoso, T \& Zulfa, E. A. (2001). Criminology. Jakarta: Raja Grafindo Perkasa. p. 55.

22 Ibid, p. 56 


\section{d. To encourage people to participate; and \\ e. To instil a sense of responsibility to the son.}

Diversion is only used to settle minor crimes, crimes without victim, or any crime that causes loss not more than the minimum wage value of the province. If the diversion process does not result in an agreement or if diversion agreement is not implemented, then the legal process will be continued. If criminal sanction should be imposed, the degree of sanction should be determined on the basis of their variative ages. Children whose age is still under 12 (twelve) years will only be subjected to treatment, whereas for those who have reached the age of 12 (twelve) up to 18 (eighteen) years, may be subjected to criminal punishment. The forms of treatment are either (a) hand it back to the parent/guardian; or (b) engage in education, coaching, and mentoring programs in government agencies. Imprisonment is only used as the last resort. The imprisonment which can be imposed on a child shall be no more than $1 / 2$ (half) of the maximum imprisonment for an adult.

\section{Conclusion}

Based on the above analysis, it can be concluded that teens commit violent crimes due to both internal and external factors. Internal factors are mostly in the forms of emotional immaturity that manifests into temperamental behavior. In addition, the personality of the perpetrator is also influential. While violence on television or internet are the most common external factors. The nature of social intercourse is another external factor which is responsible in stimulating delinquency. In attempt to overcome violent crimes by delinquents, regional police has exercised both preventive and repressive measures. With regards to the prevention of such crimes, the use of social control theory seems to be relevant. Social control theory offers various measures in approaching the problems. These include attachment, trust, commitment, and involvement. Attachment refers to the bonding to the family, peers, schools, churches, and mosques. Commitment deals with the extent to which a person maintains an interest in the social and economic system. Settlement refers to the use of the non-penal approach. However, if penalty must be imposed, its imposition should consider the issue of children protection.

\section{References}

\section{Books:}

Arief, B. N. (2008). Bunga Rampai Kebijakan Hukum Pidana (Perkembangan Penyusunan Konsep KUHP Baru(Cultivation Interest of Criminal Law Policy (Development of Drafting of New Criminal Code). Jakarta: KencanaPernada.

Central Bureau of Statistics. 2014. Criminal Statistics 2014. ISSN: 2089.5291. Publication Number: 04330.1402.

Dwi, G. M. (2013). Criminal Violence Action by The Students And Their Responsibility Efforts (Case Study In The Area Of Police Klaten. Faculty of law. University Muhammadiyah of Surakarta. 
Ibrahim, J. (2007). Teori \& Metodologi Penelitian Hukum Normatif (Theory \& Methodology of Normative Law Research). Malang: Bayumedia Publishing.

Arifin, K. A. 2017. Jogja Masih Darurat Klitih (Jogja Still A Klitih Emergency). Pranala. Edition 14.

Miles, M. B. \& Huberman, A. M. (1992) . Analisis Data Kualitatif (Qualitative Data Analysis) .Jakarta: UI Press.

Arief, M. B. N. 2005. Teori-Teori dan Kebijakan Pidana (Crime Theories and Policy). Bandung.

Romli Atmasasmita, R. (2009).Comparative Contemporary Criminal Law (Perbandingan Hukum Pidana Kontemporer). Jakarta: PT Fikahati Aneska.

Sugiharto, R \& Lestari, R. (2015). Police Measures In Criminal Infringement Motorcycle On The Road Street (Case Study in Semarang). Journal of Legal Reform. Volume II No. 2

Wignjosoebroto, S. (2007). Disertasi Sebuah Pedoman Ringkas Tentang Tatacara Penulisannya (Dissertation A Brief Guide About the Procedure of Writing). Surabaya: Laboratorium Sosiologi Fakultas Ilmu Sosial Dan Ilmu Politik Universitas Airlangga.

Santoso, T. \& Zulfa, E. A. (2001). Criminology. Jakarta: Raja Grafindo Perkasa.

Ali, Z. (2013 ). MetodePenelitianHukum. Jakarta: Sinar Grafika.

\section{Journal Article:}

Djanggih, H \& Qamar, N. (2018). Penerapan Teori-Teori Kriminologi dalam Penanggulangan Kejahatan Siber (Cyber Crime). Research Law Journal. 13(1): 1023.

Winowoda, D. (2015). Kebijakan Penanggulangan Kejahatan Kekerasan dalam Rumah Tangga di Kota Manado. Lex Crimen. IV(4):.

\section{Proceeding:}

Widowaty, Y. (2015). Cooperation of ASEAN Countries in Tackling Transnational Narcotics Crime in Facing Mea 2015.Proceeding National Conference Ke-3 Asosiasi Program Pascasarjana Perguruan Tinggi Muhammadiyah (APPPTM) Volume 2 ISBN 978-602-19568-0-9.

\section{Internet:}

krjogja.com. (2016). Menekan 'CahKlitih' di Yogyakarta(Pressing 'CahKlitih' in Yogyakarta). Accessed on Tuesday 23 Januari 2018 at 08.30 WIB.

Kriminalitas.com. (2016). Ini Penyebab Aksi Klitih Terjadi di Yogyakarta (This Cause of "Klitih" in Yogyakarta). Accessed on 22 January 2018 at 10.49 WIB.

nasional.sindonews.com. (2014). Youth Violence (KekerasanRemaja). Accessed on

Tuesday 16 Desember 2014 at 09:17 WIB 
Roda2blog.com. (2016). Tampang 11 Remaja Geng Klitih yang Meresahkan Warga Jogjakarta (Appearance 11 Teens Gang Klitih Who Disturbs the citizens of Yogyakarta). Accessed on 23 January 2018 at 12.34 WIB.

Tempo.co. (2017). DPRD Yogyakarta Rencanakan Raperda Atasi Aksi Klitih( DPRD Yogyakarta Plan Bill of Local regulation Overcome Action Klitih). Accessed on Tuesday 14 March 2017 22:06 WIB. 